\title{
European archive for mouse mutants is set to openat last
}

\section{Alison Abbott}

\section{With the rapidly burgeoning numbers of mouse mutants being produced, Europe's need for a repository and distribution centre has become urgent. The announcement that its mouse archive is to open is thus welcome.}

[ROME] The European Mouse Mutant Archive (EMMA), which has been under construction for the past three years, will open on 1 April, according to Peter Rigby, the co-chairman of its scientific policy committee.

EMMA, which has been built at Monterotondo near Rome with support from the European Commission, has been ready to accept mouse strains for several months. But its opening has been delayed because the committee, which oversees its activities, has not established all its principles of operation. There is also no full-time EMMA director.

The committee has now agreed to open the facility while detailed policy — for example on the criteria for selecting mouse strains for archiving - is being established.

At the same time, Europe's mouse-genetics community, which has complained about a lack of clarity in the committee's activities, is asking for wider representation of its members on the committee.

The committee appears to have been prompted into its announcement by last week's opening of the Adriano Buzzati Traverso international science campus, which EMMA shares with the Italian CNR Institute for Cell Biology, the European Molecular Biology Laboratory's (EMBL) Mouse Genetics Programme, and an outpost of the TriEngineering and Biotechnology. EMMA's main site at Monterotondo will have 'nodes' in France, Britain, Portugal and Sweden.

Mouse-mutant archives, which serve as a library for mouse-mutant strains created or este-based International Centre for Genetic

discovered by researchers, are becoming particularly important now that the international mouse genome programme is under way. Mouse mutants will help scientists understand the functions of genes being identified.

Over the past year, EMMA's small staff has demonstrated the facility's ability to freeze and reconstitute viable mouse embryos and transport them across Europe. But a site visit last November by the European Commission resulted in a report expressing concern that EMMA's scientific policy committee appeared to meet rarely, and had been slow to develop policies for pricing, accepting and distributing strains, and for publishing information on its archives.

Committee members are reluctant to comment on such criticisms. But many scientists suggest that inadequate and uncertain funding has meant EMMA has been unable to attract a full-time on-site director who could have applied pressure for more frequent committee meetings.

Reflecting such concerns, a task force intended to track EMMA's progress was set up last October by the International Mammalian Genome Society (IMGS), after those attending its annual meeting wanted to know how EMMA would serve the community.

But Rudi Balling, director of mammalian genetics at the GSF Institute for Environment and Health, the Munich-based national research centre that organized the meeting, says "there was a feeling that the community must make sure the repository is a success, by giving it its full support".

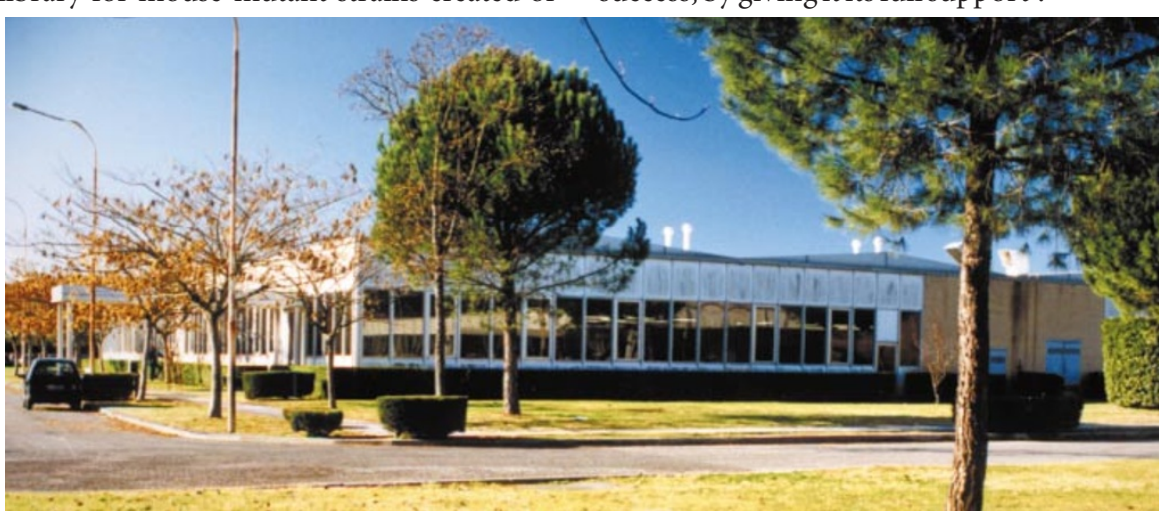

EMMA: faces concerns that its opening may have been delayed by uncertainty over funding prospects.
The demand for a mouse repository and distribution centre, already high, is expected to grow rapidly in the next five years or so. "The entire mouse genome is likely to be roughly mapped by 2003," says Peter Gruss, director of molecular and cell biology at the Max Planck Institute for Biophysical Chemistry in Göttingen and the EMMA committee's other co-chairman. "So theoretically a mutant for every important gene would need to be archived in order to allow scientists to research their functions."

The research community needs EMMA to begin operating as soon as possible, says Philip Avner, a senior scientist at the Pasteur Institute in Paris and IMGS president. "As soon as it opens, EMMA will be flooded with applications from people wanting to park their transgenics."

"Laboratories which have been working for many years with mouse mutants want to be able to distribute their strains efficiently to other interested research labs," says Klaus Rajewsky, coordinator of the EMBL programme at Monterotondo.

His own laboratory at the University of Cologne receives several requests a week for strains of his gene-targeted mutant mice, he says. "But we cannot fulfil the requests simply because of the time it takes - the best part of a day for each pair of mice."

Pressure will only increase as large-scale chemical mouse-mutagenesis screens start to produce large numbers of important strains. These screens identify interesting characteristics created when mice are administered a mutagen.

The conclusions of the IMGS task force echo the commission's concerns at the delays in policy development. "The EMMA committee must also be as responsive to the community as possible," says Avner. "So it must be expanded to include large-scale mutagenesis scientists and classical geneticists."

Rigby, who is the director of the Institute for Cancer Research in London, says the committee will meet again as soon as possible. Top of its agenda will be discussions of acceptance criteria. But these will not be too rigid, he says, as EMMA must be able to respond to scientific needs and developments: "We will have to learn by doing." The committee will also discuss its own expansion, as Rigby agrees that it must encompass the new user communities.

Finding funds to pay for a director is a clear priority, says Rigby. EMMA's two current EC grants expire this year. Once the next round of funding is secure, he says, the committee can look at how to get more 'longterm' financing for the facility.

The commission itself is reluctant to create and support permanent institutions. But, says Balling, "there is complete consensus in the mouse genetics community that EMMA should somehow be institutionalized; it is ridiculous to create such a fundamental facility on short-term money." 